\title{
Effects of the types of sealing on chemical-fermentation characteristics of corn silage from the feed out face of trench silos
}

\author{
Efeito do tipo de vedação sobre características \\ químico-fermentativas da silagem de milho na porção \\ inicial de silos trincheira
}

\begin{abstract}
Mikael Neumann; Fernando Braga Cristo2*; Giovanna Bobato Pontarolo; Marlon Richard Hilário da Silva ${ }^{3}$; Julio Cezar Heker Junior'; Fernando de Souza Sidor ${ }^{5}$; Daniel Corrêa Plodoviski ${ }^{5}$; Cherlyson Czelusniak ${ }^{5}$; Milena Pontarolo Machado ${ }^{5}$
\end{abstract}

\section{Highlights}

Double sided and double seal increased digestibility DM after 24 hours.

Double sided and double seal reduced physical losses of corn silage after 30 days.

Double sided reduced temperature of corn silage after 30 days.

\begin{abstract}
The objective of this study was to evaluate the efficiency of different types of sealing on the physical losses of dry matter, chemical and fermentation characteristics and in situ digestibility of the dry matter of corn silage stored in the feed out face (ramp) of trench silos. The experimental design used randomized blocks, composed of three treatments, namely: T1 - corn silage preserved with double-sided polyethylene of $110 \mu \mathrm{m}$ thickness (conventional seal); T2 - corn silage preserved with double-sided polyethylene of 200 $\mu \mathrm{m}$ thickness (double-sided); and T3 - corn silage preserved with oxygen-impermeable film composed of double-sided polyethylene of $80 \mu \mathrm{m}$ thickness on a translucent vacuum polyamide film of $20 \mu \mathrm{m}$ thickness (double sealing), with four repetitions each. The use of double-sided polyethylene with $200 \mu \mathrm{m}$ thickness (double-sided) and oxygen impermeable film composed of double-sided polyethylene and polyamide

1 Prof. Dr., Post Graduation Program in Plant Prodution and Veterinary Sciences, Department of Veterinary Medicine, Universidade Estadual do Centro-Oeste, UNICENTRO, Guarapuava, PR, Brazil. E-mail: neumann.mikael@hotmail.com

2 Students from the Master's Degree Program in Veterinary Sciences, Medicine Veterinary, UNICENTRO, Guarapuava, PR, Brazil. E-mail: fernandobragacristo@gmail.com; giovannabpontarolo@hotmail.com

3 Prof. Dr., Graduation in Veterinary Medicine, Department of Veterinary Medicine, Universidade Estadual do Pará, UFPA, Castanhal, PA, Brazil. E-mail: marlon_rhs@hotmail.com

${ }^{4}$ Prof. Dr., Graduation in Veterinary Medicine, Department of Veterinary Medicine, UNICENTRO, Guarapuava, PR, Brazil. E-mail:jr_heker@hotmail.com

${ }_{5}^{5}$ Discents from the Graduation the Veterinary Medicine, UNICENTRO, Guarapuava, PR, Brazil. E-mail: fernandosiddor@ gmail.com; danielplodoviski@gmail.com; cherlysonczelusniak@gmail.com; milenapontarolo98@hotmail.com

* Author for correspondence
\end{abstract}

Received: Oct. 10, 2020 - Approved: Jan. 26, 2021 
(double sealing), were effective in preserving the chemical composition, fermentation profile, raw protein composition and fiber quality, in addition, the use of these polymers resulted in greater ruminal digestibility of dry matter and reduced the $\mathrm{pH}$, temperature, temperature gradient and physical losses of corn silage from the feed out face (ramp) of trench silos compared to the conventional sealing.

Key words: Bromatology. Dry matter digestibility. Fermentation process. Nutrient loss. Nutritional composition.

\section{Resumo}

O objetivo deste estudo foi avaliar a eficiência dos diferentes tipos de vedação sobre as perdas físicas de matéria seca, as características químicas, fermentativas e digestibilidade in situ da matéria seca da silagem de milho armazenada na porção inicial (rampa) de silos trincheira. O delineamento experimental utilizado foi o de blocos casualizados, compostos por três tratamentos, sendo esses: T1 - silagem de milho conservada com polietileno dupla face com espessura de $110 \mu \mathrm{m}$ (vedação convencional); T2 - silagem de milho conservada com polietileno dupla face com espessura de 200 um (vedação dupla face); e T3 - silagem de milho conservada com película impermeável ao oxigênio composta de polietileno dupla face com espessura de $80 \mu \mathrm{m}$ sobreposta a uma película de poliamida translúcida a vácuo com espessura de $20 \mu \mathrm{m}$ (dupla vedação), com quarto repetições cada. O uso de polietileno de dupla face com espessura de $200 \mu \mathrm{m}$ (vedação dupla face) e o filme impermeável ao oxigênio composto de polietileno de dupla face e poliamida (dupla vedação), foram eficazes na conservação da composição química, perfil de fermentação, composição da proteína bruta e qualidade da fibra, além disso, o uso desses materiais na vedação proporcionou maior digestibilidade ruminal da matéria seca e reduziu os índices de $\mathrm{pH}$, temperatura, gradiente de temperatura e perdas físicas de silagem de milho da porção inicial dos silos trincheira em comparação com o tipo de vedação convencional.

Palavras-chave: Bromatologia. Digestibilidade da matéria seca. Processo fermentativo. Perda de nutrientes. Composição nutricional.

\section{Introduction}

Brazilian nutritionists have expressed great concern and dissatisfaction regarding the use of silage from the feed out face of trench silos, as there is a reduction in aspects related to nutrition, health and acceptability when compared to the food inside these silos, which has promoted fluctuations in ingestive and digestive behavior of animals, producing disturbances in production, composition, and animal immunity, when feed out starts in a new storage silo.

The feed out face of these silos is the site with greater contamination, less compaction and greater failures in the sealing at the end of the silage making process, points out that the inadequate closing and sealing of the silo enhance the action of aerobic microorganisms that cause degradation of the ensiled forage, which little resembles that in the rest of the silo (Bernardes, 2016).

The lack of regulation in the Brazilian market for these materials for exclusive use in the manufacture of silages implies the great variety of products offered, varying in price and composition (Neumann et al., 2011). The sealing of silos is made with polyethylene plastic films with a high diversity of thickness due to the low cost of acquisition and good 
mechanical resistance of the material (Bernardes, Nussio, \& Amaral, 2012), being more common the use of films with microns ranging from $70 \mu \mathrm{m}$ to $120 \mu \mathrm{m}$.

In view of this, plastic films with low oxygen permeability aim to decrease gas exchange between the interior of the silo and the atmospheric environment, thus improving the maintenance of the anaerobic environment inside the silo which is essential to obtain high quality silage (Tabacco, Ferrero, \& Borreani, 2020).

Low quality polyethylene, with low thickness and with perforations, represent the main factor that contribute to inefficient anaerobiosis of the silo (Bernardes et al., 2012). The proper sealing of the silo guarantees the reduction in oxygen permeability, promoting a decrease in losses caused by aerobic deterioration, which affects the final nutritional and hygienic quality of the silage, through the accumulation of pathogenic organisms and their toxins, which are potentially harmful to the health and food security of animals (Borreani \& Tabacco, 2010; Cavallarin, Tabacco, Antoniazzi \& Borreani, 2011).

In this context, the goal of this study was to evaluate the efficiency of different types of sealing on the physical losses of dry matter and the chemical and fermentation characteristics of corn silage from the feed out face of trench silos.

\section{Material and Methods}

All experimental procedures were previously submitted to the Ethics Committee on Animal Experimentation (CEUA), and approved for execution (Official Letter 021/2018).
The experiment was conducted in Guarapuava, State of Paraná, Brazil $\left(25^{\circ} 23^{\prime} 02^{\prime \prime}\right.$ $\mathrm{S}, 51^{\circ} 29^{\prime} 43^{\prime \prime} \mathrm{W}$, and $1098 \mathrm{~m}$ asl). The regional climate, according to the Köppen classification, is subtropical humid mesothermal (Cfb), without a dry season, with cool summers and mild winters, at an altitude of approximately $1,100 \mathrm{~m}$, with average annual rainfall of 1,944 $\mathrm{mm}$, minimum annual average temperature of $12.7^{\circ} \mathrm{C}$ and maximum annual average of $23.5^{\circ} \mathrm{C}$, with a relative humidity of $77.9 \%$.

The soil of the experimental area is classified as Dystroferric Red Latosol (Pott, Müller, \& Bertelli, 2007) and the corn crop area has been used in recent years with annual cycle pastures in the winter season, and corn crops in the summer season. At each growing season, the area is fertilized with phosphorus and potassium, according to the Manual de adubação e calagem para o estado do Paraná (2017).

The corn (Zea mays, L.) crop was planted on November 02, 2017, using seeds of the early cycle hybrid Maximus Viptera 3 (Syngenta ${ }^{\circledR}$ ), with the purpose of producing grains and silage, with hard textured grains and resistance to Glyphosate. Under no-till farming, seeds were sown in rows spaced 0.80 $\mathrm{m}$ apart, $0.04 \mathrm{~m}$ sowing depth and distribution of 5 seeds per linear meter, aiming at a final population of 62.5 thousand plants ha-1.

The basal fertilization consisted of applying $500 \mathrm{~kg} \mathrm{ha}^{-1}$ of the fertilizer 12-31-17 (NPK) and topdressing was performed with $500 \mathrm{~kg} \mathrm{ha}^{-1}$ with Nitrosulfocalciona, formula 27-00-00 + S, whose composition contains $27 \%$ N, 5\% Ca, 3.7\% S, commercial product Yara Bela Plus ${ }^{\circledR}$. The management before planting the corn crop was based on the control of undesirable plants and insects by 
the chemical method with the herbicide based on Glyphosate (commercial product Roundup WG: 2 kg ha-1), Imidacloprid + Beta-cyfluthrin (commercial product Connect: $0.75 \mathrm{~L} \mathrm{ha}^{-1}$ ) and mineral oil (commercial product Nimbus: $0.5 \mathrm{~L}$ $\mathrm{ha}^{-1}$ ). Atrazine + Simazine (commercial product Primatop: $3 \mathrm{~L} \mathrm{ha}^{-1}$ ), Nicosulfuron (commercial product Nortox: $0.7 \mathrm{~L} \mathrm{ha}^{-1}$ ) and Alphacypermethrin (commercial product Imunit: $\left.0.18 \mathrm{~L} \mathrm{ha}^{-1}\right)$, according to the technical report of the crop. The insect control was performed with Thioacetimidate $216 \mathrm{~g} \mathrm{~L}^{-1}+$ Methanol $383.5 \mathrm{~g} \mathrm{~L}^{-1}$, commercial product (Bazuka ${ }^{\circledR} 216$ $\mathrm{SL}$ at a dose of $0.60 \mathrm{~L} \mathrm{ha}^{-1}$ ).

Before silage making, samples of the whole plant and structural components: stem, leaves, bracts plus cob and grains (original material), at the kernel dent stage, were obtained in a homogeneous and representative way, weighed and predried in a forced-air oven at $55^{\circ} \mathrm{C}$. After 72 hours of drying, they were weighed again to determine the dry matter (DM) content, according to Association of Official Analytical Chemists [AOAC] (1995). This procedure allowed to estimate the productive potential of green biomass production $\left(\mathrm{kg} \mathrm{ha}^{-1}\right)$ and ensilable dry matter ( $\left.\mathrm{kg} \mathrm{ha}^{-1}\right)$, as well as the physical structure of the plant and the dry matter values of the plant and its structural components for agronomic characterization of the crop. First ear height, plant height (m) and number of dry leaves per plant were also determined (Table 1).

Corn plants were harvested at 145 days after emergence at the kernel dent stage, with the aid of a precision forage harvester $\mathrm{JF}^{\circledR}$ model (C-120 AT S2), to an average particle size of $10 \mathrm{~mm}$.

The experiment was a randomized block design consisting of three treatments: T1 - corn silage preserved with doublesided polyethylene of $110 \mu \mathrm{m}$ thickness (conventional seal); T2 - corn silage preserved with double-sided polyethylene of $200 \mu \mathrm{m}$ thickness (double-sided); and T3 - corn silage preserved with oxygen-impermeable film composed of double-sided polyethylene of $80 \mu \mathrm{m}$ thickness on a translucent vacuum polyamide film of $20 \mu \mathrm{m}$ thickness (double seal), with four repetitions each, where each repetition consisted of a silo and/or stall with two animals. 
Table 1

Agronomic characterization of the corn plant at the time of silage (2017/2018 crop)

\begin{tabular}{|c|c|}
\hline Parameter & Average value \\
\hline Green biomass production, $\left(\mathrm{kg} \mathrm{ha}^{-1}\right)$ & 63.953 \\
\hline Dry biomass production, $\left(\mathrm{kg} \mathrm{ha}^{-1}\right)$ & 23.944 \\
\hline First ear height, (m) & 1.22 \\
\hline Plant height, (m) & 2.15 \\
\hline Number of dry leaves per plant & 4.68 \\
\hline \multicolumn{2}{|c|}{ Dry matter content, $\left(\mathrm{g} \mathrm{kg}^{-1}\right)$ : } \\
\hline Stem & 201.70 \\
\hline Leaves & 307.30 \\
\hline Bract & 355.70 \\
\hline Cob & 359.00 \\
\hline Grains & 651.30 \\
\hline Whole plant & 374.30 \\
\hline Grainless plant & 262.10 \\
\hline \multicolumn{2}{|c|}{ Physical composition of the plant, $\left(\mathrm{g} \mathrm{kg}^{-1}\right)$ : } \\
\hline Stem & 153.40 \\
\hline Leaves & 255.80 \\
\hline Bract & 105.70 \\
\hline Cob & 83.50 \\
\hline Grains & 506.40 \\
\hline
\end{tabular}

The conventional seal consisted of using double-sided, polyethylene plastic film, $110 \mu \mathrm{m}$ thick, Plus Agrolord ${ }^{\circledR}$, from the company Basso Pancote. The double-sided seal consisted of using a double-sided plastic film, polyethylene with a thickness of $200 \mu \mathrm{m}$, from the company Carga Pesada ${ }^{\circledR}$. In the double seal, the plastic film Polydress ${ }^{\circledR}$ O2Barrier 2IN1, from RKW, was used, which has a layer of $80 \mu \mathrm{m}$ of a protective film composed of polyethylene, overlaid on a layer of translucent vacuum polyamide film with a thickness of 20 $\mu \mathrm{m}$, which ensures impermeability to oxygen.

The material collected for each treatment was stored in 12 trench silos, $15 \mathrm{~m}$ long, $1.2 \mathrm{~m}$ wide and $1.2 \mathrm{~m}$ high. The opening of the same occurred simultaneously, at 75 days after ensiling, and the handling for silo unloading consisted of the daily removal of $0.15 \mathrm{~m}$.

The period of silo feed out comprised 30 days of feeding confined animals, divided into two periods of 15 days, the removal of silage for feeding the animals was carried out daily at 6:00 and 16:00 hours.

Silage temperature was measured in the different treatments at 6 points on the feed out face of each silo, at 06:00, 12:00 and 16:00 hours, as well as the ambient temperature, using a metal rod digital thermometer, timer 
and current reading range between -50 to $250^{\circ} \mathrm{C}$. The temperature readings were taken at a depth of $7 \mathrm{~cm}$ in the structured mass on the face of the silos. The temperature gradient (TG) was obtained by the difference found between the ambient temperature and the temperature of the evaluated silages. In the same period, $\mathrm{pH}$ readings were also taken daily at 6:00 hours, upon unloading the silage to feed the animals, using a digital potentiometer, according to the methodology established by Cherney \& Cherney (2003).

Physical losses of silage were estimated daily in a continuous period of 30 days by weighing the silage considered visibly spoiled at the time of feed out for feeding the animals, the values obtained were corrected for the dry matter contents.

Twice a week during the feeding period of the animals, homogeneous samples of silage from the silos panel were taken, weighed and pre-dried in a forced air oven at $55^{\circ} \mathrm{C}$ to constant weight to determine the partial dry matter content (DM), being sequentially ground in a Wiley mill, with a $1 \mathrm{~mm}$ mesh sieve. In the ground samples, the total dry matter (TDM) and mineral matter (MM) contents were determined according to Silva and Queiroz (2009).

The total dry matter was determined in an oven at $105^{\circ} \mathrm{C}$ for 4 hours, crude protein (CP) by the micro Kjeldahl method, ether extract (EE) and mineral matter (MM) by incineration at $550{ }^{\circ} \mathrm{C}$ for 4 hours according to techniques described in Association of Official Analytical Chemists (AOAC, 1995). The contents of neutral detergent fiber (NDF), acid detergent fiber (ADF) and lignin (LIG) were determined according to Silva and Queiroz (2009). From these values, the hemicellulose (HEM) values were estimated by the difference between NDF and ADF, and cellulose (CEL) values by the difference between ADF and LIG values. The contents of neutral detergent insoluble protein (NDIP) and acid detergent insoluble protein (ADIP) were determined according to Van Soest, Robertson and Lewis (1991).

The total digestible nutrients (TDN, \%) were obtained via the equation [TDN,\% $=87.84$ - $(0.70 \times A D F)]$ (1), while the relative value of the food was estimated using the equation [RVF $=[(\%$ TDN $x$ DMl body weight $) / 1.29] \times 100\}$ (2), both suggested by Bolsen, Ashbell and Weinberg (1996). Non-fiber carbohydrates were estimated using the equation (NFC,\% of $\mathrm{DM}=[100-(\mathrm{NDF}+\mathrm{CP}+\mathrm{EE}+\mathrm{MM})]$ (3).

The silage dry matter ruminal degradation was estimated by the in situ technique using nylon bags with $12 \mathrm{~cm} \times 8$ $\mathrm{cm}$ and $40-60 \mu \mathrm{m}$ pores, containing $5 \mathrm{~g}$ dry sample of each material, ground to $1 \mathrm{~mm}$, for later incubation in the rumen (Nocek, 1988). The incubation times used were 24, 48 and 168 hours. The digestibility of the neutral detergent fiber was determined by measuring the neutral detergent fiber before and after ruminal incubation, according to the methodology of Goeser and Combs (2009). For this purpose, two steers were used, which are housed in the didactic unit of beef cattle sector of the Universidade Estadual do Centro Oeste, and are 48 months of age, average body weight of $650 \mathrm{~kg}$, with ruminal cannula placed by rumenotomy, previously approved by the Committee for Ethical Animal Experimentation (CEUA/UNICENTRO), under opinion 030/2014.

Estimated kinetic parameters for DM were performed as proposed by Orskov and McDonald (1979): where PD $=a+b$ (1e-ct) (4); where PD is the potential ruminal 
disappearance rate; "a" is the soluble fraction corresponding to 0 hours of incubation; "b" is the fraction potentially degradable in the rumen corresponding to 24 hours of incubation by subtracting from fraction "a"; and "c" is the fraction non-degradable in the rumen (100 - value degraded within 24 hours) (5) (Goes et al., 2010).

The concentration of lactic acid was estimated according to the methodology described by Price (1969). The concentrations of acetic and lactic acids in the samples were determined by gas chromatography using a Shimadzu ${ }^{\odot}$ GC-2010 Plus chromatograph equipped with an AOC-20i automatic injector, Stabilwax-DA ${ }^{\mathrm{TM}}$ capillary column $(30 \mathrm{~m}$, $0.25 \mathrm{~mm}$ ID, $0.25 \mu \mathrm{m} \mathrm{df}$, Restek $^{\odot}$ ) and flame ionization detector (FID), after acidifying them with $1 \mathrm{M}$ phosphoric acid p.a. (Ref. 100573, Merck $^{\odot}$ ) and fortification with the WSFA-2 standard (Ref. 47056, Supelco ${ }^{\odot}$ ). The sample collected from each silage was $15 \mathrm{~g}$, which were homogenized in a blender with $200 \mathrm{~mL}$ distilled water. After homogenizing for one minute, the sample was sieved and centrifuged, a volume of $1 \mu \mathrm{L}$ was taken. This sample was injected at a 40: 1 split ratio, using helium as carrier gas at a linear speed of 42 $\mathrm{cm} . \mathrm{s}^{-1}$, obtaining the separation of the analytes in a chromatographic run of 11.5 minutes. The injector and detector temperatures were 250 ${ }^{\circ} \mathrm{C}$ and $300{ }^{\circ} \mathrm{C}$, respectively, and the initial column temperature was $40{ }^{\circ} \mathrm{C}$. The column temperature ramp started with a gradient from 40 to $120^{\circ} \mathrm{C}$ at a rate of $40^{\circ} \mathrm{C} \mathrm{min}{ }^{-1}$, followed by a gradient from 120 to $180{ }^{\circ} \mathrm{C}$ at a rate of $10{ }^{\circ} \mathrm{C} \mathrm{min}-1$ and from 180 to $240{ }^{\circ} \mathrm{C}$ at a rate of $120{ }^{\circ} \mathrm{C} \mathrm{min}{ }^{-1}$, keeping the temperature at $240{ }^{\circ} \mathrm{C}$ for another 3 minutes at the end. For quantification of the analytes, a calibration of the method was carried out with dilutions of the WSFA-2 standard (Ref. 47056, Supelco ${ }^{\circ}$ ) of glacial acetic acid (Ref. 33209, SigmaAldrich $^{\odot}$ ) and HPLC grade ethanol (Ref. 459828, Sigma-Aldrich ${ }^{\odot}$ ) analyzed under the conditions described above. The detection and integration of the peaks were made using the GCsolution software v. 2.42.00 (Shimadzu ${ }^{\odot}$ ).

Data collected for each variable were tested by analysis of variance with comparison of the means by Tukey's test at $5 \%$ significance, using the SAS statistical software (Statistical Analysis System Institute [SAS Institute], 1993).

\section{Results and Discussion}

Regarding the chemical composition of corn silages from the feed out face of trench silos with different types of sealing, it is noted that the type of sealing influenced ( $P$ $<0.05$ ) the DM contents, and the silo with the conventional seal had lower DM values (412.20 $\mathrm{g} \mathrm{kg}^{-1}$ DM) than those obtained by doublesided and double seal with values of 425.80 $\mathrm{g} \mathrm{kg}^{-1} \mathrm{DM}$ and $428.30 \mathrm{~g} \mathrm{~kg}^{-1} \mathrm{DM}$, respectively (Table 2).

Likewise, the contents of $\mathrm{MM}$ and $\mathrm{CP}$ varied in relation to the sealing system (Table 2). The double-sided treatment resulted in higher values $(P<0.05)$ of $M M$ compared to the double seal $\left(33.60 \mathrm{~g} \mathrm{~kg}^{-1} \mathrm{DM}\right.$ and $27.10 \mathrm{~g}$ $\mathrm{kg}^{-1} \mathrm{DM}$, respectively), a result that is repeated considering the $\mathrm{CP}$, where the double-sided treatment $\left(67.20 \mathrm{~g} \mathrm{~kg}^{-1} \mathrm{DM}\right)$ presented the highest value in relation to the other types of sealing, which did not differ statistically from each other $(P>0.05)$.

Possibly the greater interaction of silage with the external medium in the conventional seal provided a higher cellular 
respiratory rate after closing the silo and greater action of aerobic microorganisms, which led to a greater production of water and $\mathrm{CO}_{2}$ in the process, thus decreasing the DM content in the resulting silage and generating variations in the contents of $\mathrm{MM}$ and $\mathrm{CP}$ in the present study, because when sealing is efficient, oxygen is rapidly consumed by respiratory activity of ensiled forage and there is a decrease in temperature and inhibition of aerobic microorganism activity (Borreani, Dolci, Tabacco, \& Cocolin, 2013).

\section{Table 2}

Chemical composition of corn silages from the feed out face of trench silos using different types of sealing

\begin{tabular}{|c|c|c|c|c|c|c|}
\hline \multirow{2}{*}{ Parameter* } & \multicolumn{3}{|c|}{ Types of sealing } & \multirow{2}{*}{ Mean } & \multirow{2}{*}{ P-value } & \multirow{2}{*}{ SEM } \\
\hline & Conventional Seal & Double Sided & Double Seal & & & \\
\hline $\mathrm{DM},\left(\mathrm{g} \mathrm{kg}^{-1}\right)$ & $412.20 \mathrm{~b}$ & $425.80 \mathrm{a}$ & $428.30 \mathrm{a}$ & 422.10 & 0.0091 & 0.512 \\
\hline$M M,\left(g ~ k g^{-1}\right)$ & $29.10 a b$ & $33.60 \mathrm{a}$ & $27.10 b$ & 29.90 & 0.0151 & 0.064 \\
\hline$C P,\left(g ~ k g^{-1}\right)$ & $60.10 \mathrm{~b}$ & $67.20 \mathrm{a}$ & $60.60 \mathrm{~b}$ & 62.60 & 0.0400 & 0.098 \\
\hline $\mathrm{EE}_{,}\left(\mathrm{g} \mathrm{kg}^{-1}\right)$ & $28.90 \mathrm{a}$ & $29.40 \mathrm{a}$ & $30.0 \mathrm{a}$ & 29.60 & 0.2974 & 0.061 \\
\hline NFC, $\left(\mathrm{g} \mathrm{kg}^{-1}\right)$ & $333.30 \mathrm{a}$ & $356.60 \mathrm{a}$ & $348.30 \mathrm{a}$ & 346.10 & 0.4961 & 1.330 \\
\hline NDF, $\left(\mathrm{g} \mathrm{kg}^{-1}\right)$ & 548.60 a & $513.30 \mathrm{a}$ & $533.60 \mathrm{a}$ & 531.80 & 0.2271 & 1.279 \\
\hline HEM, $\left(\mathrm{g} \mathrm{kg}^{-1}\right)$ & $256.30 \mathrm{a}$ & $242.70 \mathrm{a}$ & $243.80 a$ & 247.60 & 0.7162 & 1.268 \\
\hline$A D F,\left(\mathrm{~g} \mathrm{~kg}^{-1}\right)$ & 292.30 a & $270.60 \mathrm{a}$ & $289.80 \mathrm{a}$ & 284.20 & 0.3572 & 1.074 \\
\hline CEL, $\left(\mathrm{g} \mathrm{kg}^{-1}\right)$ & $222.70 \mathrm{a}$ & $204.00 \mathrm{a}$ & $224.20 \mathrm{a}$ & 217.00 & 0.4904 & 1.253 \\
\hline LIG, $\left(\mathrm{g} \mathrm{kg}^{-1}\right)$ & $69.60 \mathrm{a}$ & $66.60 \mathrm{a}$ & $65.60 \mathrm{a}$ & 67.30 & 0.5372 & 0.250 \\
\hline TDN, $\left(\mathrm{g} \mathrm{kg}^{-1}\right)$ & $673.80 \mathrm{a}$ & $689.00 \mathrm{a}$ & $675.50 \mathrm{a}$ & 679.40 & 0.3589 & 0.754 \\
\hline RVF & $114.5 b$ & 124.9 a & $118.0 \mathrm{ab}$ & 119.2 & 0.0205 & 3.635 \\
\hline
\end{tabular}

* DM: dry matter; MM: mineral matter; CP: crude protein; EE: ether extract; NFC: Non-fiber carbohydrates; NDF: neutral detergent fiber; HEM: hemicellulose; ADF: acid detergent fiber; CEL: cellulose; LIG: lignin; TDN: total digestible nutrients; and RVF: relative value of food.

Mean values followed by different lowercase letters, in the same row, are significantly different by Tukey's Test ( $\rho<0.05)$.

RVF values were also influenced by the type of sealing, and the double-sided seal showed a higher value compared to the double seal and conventional treatments (118.0 and 114.5, respectively). While the other parameters (Table 2) were not influenced by the type of sealing $(P>0.05)$.

After 24 hours of ruminal incubation, the double seal and double-sided seal did not differ from each other $(P>0.05)$, but they were superior to the conventional seal $(60.20$ $\mathrm{g} \mathrm{kg}^{-1} \mathrm{DM}$ and $60.70 \mathrm{~g} \mathrm{~kg}^{-1} \mathrm{DM}$, respectively), advancing to 48 hours of ruminal incubation, the double-sided treatment proved to be superior to the other types of sealing $(P<0.05)$, with superior digestibility in $28.20 \mathrm{~g} \mathrm{~kg}^{-1} \mathrm{DM}$ versus the double seal and $54.30 \mathrm{~g} \mathrm{~kg}^{-1} \mathrm{DM}$ versus conventional sealing (Table 3 ). 
Table 3

Digestibility and in situ ruminal degradation of dry matter of corn silage from the feed out face of trench silos using different types of sealing

\begin{tabular}{|c|c|c|c|c|c|c|}
\hline \multirow{2}{*}{ Parameter } & \multicolumn{3}{|c|}{ Types of sealing } & \multirow{2}{*}{ Mean } & \multirow{2}{*}{ P-value } & \multirow{2}{*}{ SEM } \\
\hline & Conventional Seal & Double Sided & Double Seal & & & \\
\hline Digestibility DM: & \multicolumn{6}{|c|}{$\left(\mathrm{g} \mathrm{kg}^{-1} \mathrm{DM}\right)$} \\
\hline 24 hours incubation & $481.30 b$ & $541.50 a$ & $542.00 a$ & 521.60 & 0.0459 & 1.583 \\
\hline 48 hours incubation & $618.70 c$ & $673.00 a$ & $644.80 b$ & 645.50 & 0.0003 & 0.413 \\
\hline 168 hours incubation & $705.60 b$ & $726.90 b$ & $769.80 a$ & 734.10 & 0.0070 & 0.914 \\
\hline Degradation ruminal DM: & \multicolumn{6}{|c|}{$\left(\mathrm{g} \mathrm{kg}^{-1} \mathrm{DM}\right)$} \\
\hline Soluble fraction & $192.20 a$ & $164.60 \mathrm{~b}$ & $160.50 \mathrm{~b}$ & 172.40 & 0.0382 & 0.709 \\
\hline Fraction degradable & $426.50 b$ & $508.40 a$ & 484.30a & 473.10 & 0.0004 & 0.684 \\
\hline Insoluble fraction & $381.30 a$ & $327.00 c$ & $355.20 b$ & 354.50 & 0.0003 & 0.413 \\
\hline
\end{tabular}

Mean values followed by different lowercase letters, in the same row, are significantly different by Tukey's Test $(\rho<0.05)$.

However, when evaluating the degradation after 168 hours of ruminal incubation (Table 3), the double seal $(769.80 \mathrm{~g}$ $\mathrm{kg}^{-1} \mathrm{DM}$ ) stood out with the highest digestibility $(P<0.05)$ in relation to the conventional and double-sided treatments which did not differ from each other $(P>0.05)$ (705.60 $\mathrm{g} \mathrm{kg}^{-1} \mathrm{DM}$ and $726.90 \mathrm{~g} \mathrm{~kg}^{-1} \mathrm{DM}$, respectively).

The conventional sealing had the highest soluble fraction (192.20 $\mathrm{g} \mathrm{kg}^{-1} \mathrm{DM}$ ), but obtained the smallest degradable portion (426.50 $\mathrm{g} \mathrm{kg}^{-1} \mathrm{DM}$ ) and the largest insoluble portion (381.30 $\mathrm{g} \mathrm{kg}^{-1} \mathrm{DM}$ ) in relation to the other types of sealing (Table 3 ).

The feed out face of trench silos is the portion of the silo with the most challenging environment for silage preservation, due to the difficulty of compacting and sealing the site, so it is suggested that there is a greater influence of the type of sealing used, impacting on the quality of the fermentation process and consequently in the ruminal degradability of the material. Neumann et al. (2017) evaluated the digestibility of corn silage dry matter under different types of sealing in trench silos, and reported no statistical difference between conventional and double sealing systems, differently from that found in this research, where the silage from the conventional sealing presented the lowest ruminal digestibility in relation to the types of sealing.

The lactic acid content did not differ statistically $(P>0.05)$ between the types of sealing used in trench silos. However, in relation to acetic acid, the conventional seal presented the highest values $(P<0.05)(31.60$ $\left.\mathrm{g} \mathrm{kg}^{-1} \mathrm{DM}\right)$ compared to the double-sided seal (22.80 $\mathrm{g} \mathrm{kg}^{-1} \mathrm{DM}$ ) and double seal (23.90 $\mathrm{g} \mathrm{kg}^{-1}$ $D M)$ which did not differ statistically $(P>0.05)$ (Table 4). 
Table 4

Fermentation profile, crude protein composition and fiber digestibility in corn silage neutral detergent from the feed out face of trench silos using different types of sealing

\begin{tabular}{|c|c|c|c|c|c|c|}
\hline \multirow{2}{*}{ Parameter } & \multicolumn{3}{|c|}{ Types of sealing } & \multirow{2}{*}{ Mean } & \multirow{2}{*}{ P-value } & \multirow{2}{*}{ SEM } \\
\hline & Conventional Seal & Double Sided & Double Seal & & & \\
\hline \multicolumn{7}{|c|}{$\left(\mathrm{g} \mathrm{kg}^{-1} \mathrm{DM}\right)$} \\
\hline Latic Acid & $50.10 a$ & $55.30 \mathrm{a}$ & $54.40 \mathrm{a}$ & 53.30 & 0.1113 & 0.139 \\
\hline Acetic Acid & $31.60 \mathrm{a}$ & $22.80 \mathrm{~b}$ & $23.90 \mathrm{~b}$ & 26.10 & 0.0469 & 0.211 \\
\hline \multicolumn{7}{|c|}{ (g kg-1 CP) } \\
\hline NDIP & $146.70 \mathrm{a}$ & $155.00 \mathrm{a}$ & $153.30 \mathrm{a}$ & 151.60 & 0.2314 & 0.299 \\
\hline ADIP & $74.10 \mathrm{~b}$ & $86.00 \mathrm{a}$ & $71.10 \mathrm{~b}$ & 77.00 & 0.0068 & 1.732 \\
\hline $\mathrm{NH}_{3}$ & $83.20 \mathrm{a}$ & $62.70 \mathrm{~b}$ & 73.10ab & 73.00 & 0.0241 & 0.281 \\
\hline \multicolumn{7}{|c|}{ NDF digestible, ( $\mathrm{kg}^{-1} \mathrm{NDF}$ ) } \\
\hline NDFd, $24 \mathrm{~h}$. & $377.50 \mathrm{~b}$ & $408.30 \mathrm{a}$ & $394.50 a b$ & 393.50 & 0.0095 & 0.359 \\
\hline NDFd, $48 \mathrm{~h}$. & $521.00 \mathrm{c}$ & $574.70 \mathrm{a}$ & $548.30 \mathrm{~b}$ & 548.00 & 0.0001 & 0.180 \\
\hline \multicolumn{7}{|c|}{ NDF indigestible, ( $\left.\mathrm{g} \mathrm{kg}^{-1} \mathrm{NDF}\right)$} \\
\hline NDFi, $120 \mathrm{~h}$. & $179.70 \mathrm{a}$ & $154.70 \mathrm{~b}$ & $163.40 \mathrm{ab}$ & 165.90 & 0.0179 & 0.352 \\
\hline NDFi, $240 \mathrm{~h}$. & $162.70 \mathrm{a}$ & $144.00 \mathrm{c}$ & $153.00 \mathrm{~b}$ & 154.60 & 0.0016 & 0.164 \\
\hline
\end{tabular}

* NDIP= Neutral detergent insoluble protein; $\mathrm{ADIP}=$ Acid detergent insoluble protein; $\mathrm{NH}_{3}=$ Ammonia; NDFd= Digestible neutral detergent fiber; NDFi= Indigestible neutral detergent fiber.

Mean values followed by different lowercase letters, in the same row, are significantly different by Tukey's Test $(\rho<0.05)$.

The type of sealing besides influencing the chemical composition of corn silages from the feed out face of trench silos also positively influenced the fermentation profile of these silages, although the different types of sealing did not result in statistical difference in the values of lactic acid. During the fermentation period, lactic acid indicates that the anaerobic environment was installed quickly inside the silo and was maintained until silo opening, with no excessive consumption of soluble sugars by aerobic microorganisms after closing the silo, also impacting on the corn silage digestibility (Borreani \& Tabacco, 2017).

Borreani and Tabacco (2014) found higher amounts of lactic acid in silages sealed with oxygen barrier plastic film compared to those sealed with conventional films; the authors attribute the highest amount of lactic acid in the type of sealing with oxygen barrier film to fast installation and preservation of the anaerobic environment inside the silo. For Wilkinson and Davies (2013), lactic acid after opening the silo is used as a substrate of excellent availability mainly for yeasts, resulting in nutrient consumption and silage with low aerobic stability.

When the different crude protein fractions were evaluated, it was observed that the neutral detergent insoluble protein (NDIP) did not change due to the type of sealing $(P>0.05)$, however, the other protein fractions were influenced by the type of sealing, and the types of sealing showed statistical difference 
from each other $(\mathrm{P}<0.05)$. The double-sided seal had the highest fraction of acid detergent insoluble protein (ADIP) (86.00 $\mathrm{g} \mathrm{kg}^{-1} \mathrm{CP}$ ) in relation to the other types of sealing, which did not differ from each other $(P>0.05)$. And the double-sided seal had the lowest content of $\mathrm{NH}_{3}(\mathrm{P}<0.05)$ compared to the conventional seal $\left(62.70 \mathrm{~g} \mathrm{~kg}^{-1} \mathrm{CP}\right.$ and $83.20 \mathrm{~g} \mathrm{~kg}^{-1} \mathrm{CP}$, respectively) (Table 4).

The prolongation of the time for achieving the anaerobic environment and difficulties in its maintenance are due to the presence of residual oxygen in the ensiled mass or failures in the sealing, thus allowing the entry of atmospheric oxygen inside the silo, causing proteolysis by microbial action forming mainly amino acids and ammonia (Fijałkowska, Pysera, Lipiński, \& Strusińska 2015). Still, high concentrations of ammonia can decrease the intake of silage byanimals and reduce th,e efficiency in the use of nitrogen for protein synthesis by rumen microorganisms, and also cause changes in the course of fermentation, preventing the rapid drop in the $\mathrm{pH}$ of the ensiled mass, favoring the growth of undesirable microorganisms (Fijałkowska et al., 2015). This can justify the higher $\mathrm{pH}$ obtained in the conventional sealing (Table 5).

It is possible to observe that the double-sided seal showed the highest proportions $(\mathrm{P}<0.05)$ of digestible neutral detergent fiber (NDFd) in both 24 hours and 48 hours (408.30 $\mathrm{g} \mathrm{kg}^{-1} \mathrm{NDF}$ and $574.70 \mathrm{~g}$ $\mathrm{kg}^{-1} \mathrm{NDF}$ ) compared to the conventional seal (377.50 $\mathrm{g} \mathrm{kg}^{-1} \mathrm{NDF}$ and $521.00 \mathrm{~g} \mathrm{~kg}^{-1} \mathrm{NDF}$ ). This result is complemented by assessing the content of indigestible neutral detergent fiber
(NDFi), in which the conventional seal showed the highest values $(P<0.05)$ both in 120 hours and in 240 hours $\left(179.70 \mathrm{~g} \mathrm{~kg}^{-1}\right.$ NDF and 162.07 $\mathrm{g} \mathrm{kg}^{-1} \mathrm{NDF}$, respectively) in relation to the other types of sealing (Table 4).

According to Kung, Shaver, Grant and Schmidt (2018), NH3 grading can be used as an indicator of the efficiency of fermentation, in which silages with less than $10 \% \mathrm{NH}_{3}$ are considered as an efficient preservation of ensiled material. In general, high humidity silages have higher concentrations of $\mathrm{NH}_{3}$ than dryer silages because of the more intense general fermentation in the former, and when the levels are higher than normal they are usually the result of the proteolytic activity of the clostrids (Kung et al., 2018).

Neumann et al. (2017) evaluated the digestible portion of the NDF fraction from corn silage subjected to different types of sealing, and reported that the digestibility of the double sealing system was $25.54 \%$ higher than the conventional system. Bernardes et al. (2012) also found a $6 \%$ increase in NDF digestibility in double sealing compared to conventional sealing. These increments were attributed by the authors to the preservation of the anaerobic environment inside the silo. A result similar to that found in the present study, where after 48 hours of ruminal incubation, the double-sided seal was $9.34 \%$ and the double seal was $4.98 \%$ higher than the conventional seal, allowing to suggest that the doublesided seal was more effective in maintaining the anaerobic environment in relation to conventional sealing. 


\section{Table 5}

Mean values of dry matter, $\mathrm{pH}$, silage temperature, temperature gradient and physical losses of dry matter during the experimental period of corn silage from the feed out face of trench silos using different types of sealing

\begin{tabular}{|c|c|c|c|c|}
\hline \multirow{2}{*}{$\begin{array}{l}\text { Period of } \\
\text { Evaluation }\end{array}$} & \multicolumn{3}{|c|}{ Types of sealing } & \multirow{2}{*}{ Mean } \\
\hline & Conventional Seal & Double Sided & Double Seal & \\
\hline & \multicolumn{4}{|c|}{ Dry matter, $\left(\mathrm{g} \mathrm{kg}^{-1}\right)$} \\
\hline 0 to 15 days & 410.80 & 422.10 & 438.70 & $423.80 \mathrm{~A}$ \\
\hline 16 to 30 days & 413.70 & 429.60 & 417.90 & $420.40 \mathrm{~A}$ \\
\hline \multirow[t]{2}{*}{ Mean } & $412.20 \mathrm{~b}$ & 425.90ab & $428.30 \mathrm{a}$ & \\
\hline & \multicolumn{4}{|c|}{$\mathrm{pH}$} \\
\hline 0 to 15 days & 4.17 & 4.05 & 4.10 & $4.11 \mathrm{~A}$ \\
\hline 16 to 30 days & 4.12 & 4.07 & 4.09 & $4.09 \mathrm{~A}$ \\
\hline \multirow[t]{2}{*}{ Mean } & $4.14 \mathrm{a}$ & $4.06 \mathrm{~b}$ & 4.10ab & \\
\hline & \multicolumn{4}{|c|}{ Temperature, $\left({ }^{\circ} \mathrm{C}\right)$} \\
\hline 0 to 15 days & 21.25 & 19.15 & 18.90 & $19.77 \mathrm{~A}$ \\
\hline 16 to 30 days & 21.13 & 19.10 & 20.81 & $20.35 \mathrm{~A}$ \\
\hline \multirow[t]{2}{*}{ Mean } & $21.19 \mathrm{a}$ & $19.12 b$ & $19.85 a b$ & \\
\hline & \multicolumn{4}{|c|}{ Temperature gradient, $\left({ }^{\circ} \mathrm{C}\right)$} \\
\hline 0 to 15 days & 3.22 & 1.13 & 0.88 & $1.74 \mathrm{~B}$ \\
\hline 16 to 30 days & 5.91 & 3.89 & 5.60 & $5.13 \mathrm{~A}$ \\
\hline \multirow[t]{2}{*}{ Mean } & $4.56 \mathrm{a}$ & $2.51 \mathrm{c}$ & $3.24 b$ & \\
\hline & \multicolumn{4}{|c|}{ Physical losses, (g kg-1 DM) } \\
\hline 0 to 15 days & 69.00 & 47.00 & 50.00 & $55.33 \mathrm{~B}$ \\
\hline 16 to 30 days & 131.00 & 90.00 & 114.00 & $111.66 \mathrm{~A}$ \\
\hline Mean & $100.00 \mathrm{a}$ & $68.50 \mathrm{c}$ & $82.00 \mathrm{~b}$ & \\
\hline
\end{tabular}

Mean values followed by different lowercase letters, in the same row, are significantly different by Tukey's Test $(\rho<0.05)$.

Yeasts and filamentous fungi degrade non-fiber carbohydrates, resulting in an increase in the concentration of fiber carbohydrates. The higher multiplication of yeasts may be related to higher $\mathrm{pH}$ values, lower NDF digestibility and greater permeability of the plastic film to gases in the external environment. The NDF digestibility of corn silage is correlated to intake, relevant to rumen filling, and utilization by the animal, so the optimization of the use of this fiber fraction results in better growth performance (Bernardes et al., 2012).

Ferraretto and Shaver (2015) report that foods with higher NDF degradation rates allow a significant increase in dry matter intake and an increase in milk production, due to less rumen filling, and may reduce costs, due to improved ruminal health, corresponding to a higher frequency of rumination, higher concentration of milk fat and less participation 
of concentrate in the diet. This allows to suggest that silage from the double-sided treatment would be used more efficiently by animals, since it has the largest digestible portions of NDF and the smallest indigestible portions of NDF.

In relation to the types of sealing, there was influence on the dry matter content of the silages $(P<0.05)$. The double seal obtained the highest percentages of DM compared to the conventional seal $\left(428.3 \mathrm{~g} \mathrm{~kg}^{-1}\right.$ and $412.20 \mathrm{~g}$ $\mathrm{kg}^{-1}$, respectively) (Table 5).

Borreani et al. (2013) stated that the use of oxygen barrier films promote improvement in aerobic stability, as they lead to lower losses of dry matter due to deterioration by microorganisms, especially in the feed out the face with greater propensity to accumulate oxygen, due to less exchange of gases between the atmospheric environment and the internal environment of the silo.

Similarly to dry matter, the daily $\mathrm{pH}$ was affected by the type of sealing $(P<0.05)$, as the conventional seal had the highest $\mathrm{pH}$ in relation to the double-sided system $(4.14 \%$ and $4.06 \%$, respectively), whereas the double seal did not differ from the other types of sealing tested $(P>0.05)$.

Still according to Borreani et al. (2013), silages sealed with conventional polyethylene films, but without mentioning the thickness and quality of the materials, have greater activity of yeasts and molds that lead to the consumption of organic acids present in the silage, causing an increase in the $\mathrm{pH}$ and temperature of the silo. This is related to the exposure of the silage to oxygen during the preservation period, due to the sealing difficulties that these plastic films present and the poor management of the silo closing and sealing process in most silage-producing farms.

The silage from the conventional sealing system had the highest $\mathrm{pH}$ values and the lowest CP contents (Table 2) in relation to the types of sealings evaluated, allowing to suggest that there was greater proteolytic activity and possibly greater activity of spoilage microorganisms, which can be attributed to the ability to achieve and maintain the anaerobic environment by the material used to seal the silo.

Higher $\mathrm{pH}$ values obtained in conventionally sealed silos may be related to greater oxygen infiltration from the tarpaulin, allowing degradation of ensiled material and a consequent increase in $\mathrm{pH}$ (Gallo, Guibert, Frisvad, Bertuzzi, \& Nielsen, 2015).

The increase in the amount of yeasts present in the silage after opening the silo causes an increase in $\mathrm{pH}$ and temperature, creating an environment conducive to the development of microorganisms less tolerant to acid, such as Clostridium and Bacillus, these types of silagesundesirable, due to their lower nutritional value and increased risk of negative effects on animal performance, they are also associated with the proliferation of microorganisms with pathogenic potential or other undesirable forms (Tabacco, Righi, Quarantelli, \& Borreani, 2011).

The temperature at the feed out face of the silos differed statistically between the types of sealing $(P<0.05)$ (Table 5$)$. The conventional seal achieved the highest temperature averages $\left(21.19^{\circ} \mathrm{C}\right)$, which was 9.77\% higher compared to the double-sided system $\left(19.12^{\circ} \mathrm{C}\right)$, and $6.32 \%$ higher compared to the double seal system $\left(19.85^{\circ} \mathrm{C}\right)$. 
Taking into account the gradient of ambient temperature in relation to the temperature at the feed out face of the trench silos, the double-faced sealing stood out $(P$ $<0.05)$ with the smallest variation $\left(2.51^{\circ} \mathrm{C}\right)$ in relation to conventional seal, which showed the highest temperature gradient $\left(4.56^{\circ} \mathrm{C}\right)$, the double seal reached intermediate values (3.24 ${ }^{\circ} \mathrm{C}$ ) between the types of sealing evaluated. Regarding the evaluation periods, it is notable that there was an increase in the temperature gradient over the experimental periods (1.74 ${ }^{\circ} \mathrm{C}$ vs $5.13^{\circ} \mathrm{C}$ ).

In the same way, Junga and Trávnicek (2015) argued that the increase in temperature of the ensiled mass originates from the degradation of substrates, mainly by fungi and yeasts, which act in the presence of oxygen resulting in the elevation of the average $\mathrm{pH}$ values and lower nutritional value of the food due to aerobic deterioration.

Neumann et al. (2017), in a similar study, evaluated double sealing and conventional sealing, and reported average temperatures higher than those obtained in the present study $\left(30.18^{\circ} \mathrm{C}\right.$ and $31.48^{\circ} \mathrm{C}$, respectively), and attributed the increase in silage temperature in the silo feed out face with the activity of aerobic spoilage microorganisms.

Arriola, Kim and Adesogan (2011) consider that there is loss of aerobic stability and onset of aerobic degradation in the silage when the temperature of the silage exceeds ambient temperature by more than $2{ }^{\circ} \mathrm{C}$. This demonstrates that in the first experimental period (0-15 days) only the silage from the conventional treatment lost aerobic stability in the silo feed out face, demonstrating the greater activity of aerobic microorganisms.
For Bernardes (2016), the increase in temperature is a strong indicator of multiplication of microorganisms, which is only possible in the presence of oxygen, allowing several aerobic spoilage microorganisms to become active and multiply, resulting in substantial economic losses. The degradation of silage is indicated by an increase in temperature, an increase in $\mathrm{pH}$, loss of dry matter, growth of surface molds and the refusal of this food by the animals, conditions observed in silage from the conventional sealing.

There was an increase in physical losses from the first period (55.33 $\mathrm{g} \mathrm{kg}^{-1} \mathrm{DM}$ ) to the second period (111.66 $\mathrm{g} \mathrm{kg}^{-1} \mathrm{DM}$ ) (Table 5). When analyzing the different types of sealing, it is possible to verify a statistical difference $(P<0.05)$, the conventional seal obtained the largest physical losses, $\left(\mathrm{g} \mathrm{kg}^{-1} \mathrm{DM}\right)\left(100 \mathrm{~g} \mathrm{~kg}^{-1}\right.$ $\mathrm{DM})$ in relation to the double seal $\left(82 \mathrm{~g} \mathrm{~g} \mathrm{~kg}^{-1}\right.$ $\mathrm{DM})$ and the double-sided seal (68.5 $\left.\mathrm{g} \mathrm{kg}^{-1} \mathrm{DM}\right)$, which obtained the smallest losses among all types of sealing.

Lima et al. (2017) evaluated dry matter losses using different types of sealing, and found that losses were reduced by about $50 \%$ with the use of oxygen-impermeable film. The authors obtained $4.91 \%$ dry matter losses in sealing with oxygen barrier film and $10.9 \%$ for conventional sealing, showing the importance of the plastic film used to seal the silos, impacting the quality and amount of the resulting food.

Bernardes etal. (2012) attribute the high losses of dry matter to a greater permeability to oxygen in the plastic film and also state that the double seal favors the achievement and maintenance of the appropriate anaerobic 
conditions for preservation of ensiled forage in regions of the silo where there is greater susceptibility to losses, like the feed out faces of the silos. Corroborating the present study, in which the conventional sealing of the silage resulted in the greatest physical losses in relation to the other types of sealing.

Wilkinson and Fenlon (2014) compared 51 silos sealed with conventional film and oxygen barrier and found that, in 43 of these, losses were greater for silos using conventional sealing.

According to Borreani and Tabacco (2014), the use of sealing with higher technology used in plastic films, despite having a higher acquisition cost, provides greater economic benefit, due to the resultant silages with better fermentation profile, lower losses of dry matter and less silage discarded due to better silage preservation and less deterioration, requiring less work to dispose these materials. In agreement with Bernardes (2016), for every \$ 1.00 invested in plastic film and labor to seal the silo, there is an economic return of $\$ 8.00$ in loss reduction and better use of food, especially in areas with difficulty in achieving and maintaining the anaerobic environment.

\section{Conclusion}

Sealing systems with $200-\mu m$ thick double-sided polyethylene and double sealing with oxygen-impermeable film were effective and promoted improvements in chemical composition, ruminal degradation of $D M$, fermentation profile and physical losses of corn silages from the feed out face of trench silos compared to conventional sealing.

\section{References}

Arriola, K. G., Kim, S. C., \& Adesogan, A. T. (2011). Effect of applying inoculants with heterolactic or homolactic and heterolactic bacteria on the fermentation and quality of corn silage. Journal of Dairy Science, 94(3), 1511-1516. doi: 10.3168/ jds.2010-3807

Association of Official Analytical Chemists (1995). Official methods of analysis (16a ed.). Washington, D.C.: AOAC.

Bernardes, T. F. (2016). Advances in silage sealing. In T. Silva, \& E. M. Santos (Eds.), Advances in silage production and utilization (pp. 53-62). London: InTech.

Bernardes, T. F., Nussio, L. G., \& Amaral, R. C. (2012). Top spoilage losses in maize silage sealed with plastic films with different permeabilities to oxygen. Grass and Forage Science, 67(1), 34-42. doi: 10. 1111/j.1365-2494.2011.00823.x

Bolsen, K. K., Ashbell, G., \& Weinberg, Z. G. (1996). Silage fermentation and silage additives-Review. Asian-Australasian Journal of Animal Sciences, 9(5), 483-494. doi: 10.5713/ajas.1996.483

Borreani, G., Dolci, P., Tabacco, E., \& Cocolin, L. (2013). Aerobic deterioration stimulates out growth of spore-forming Paenibacillus in corn silage store dunder oxygen-barrier or polyethylene films. Journal Dairy Science, 96(8), 5206-5216. doi: 10.3168/ jds.2013-6649

Borreani, G., \& Tabacco, E. (2010). The relationship of silage temperature with the microbiological status of the face of corn silage bunkers. Journal of Dairy Science, 93(6), 2620-2629. doi: 10.3168/ jds.2009-2919 
Borreani, G., \& Tabacco, E. (2014). Improving corn silage quality in the top layer of farm bunker silos through the use of a next generation barrier film with high impermeability to oxygen. Journal Dairy Science, 97(4), 2415-2426. doi: 10.3168/ jds.2013-7632

Borreani, G., \& Tabacco, E. (2017). Plastics in animal production. In: M. D. Orzole (Ed.), $A$ guide to the manufacture, performance, and potential of plastics in agriculture (pp. 145-185). Oxford: Elsevier.

Cavallarin, L., Tabacco, E., Antoniazzi, S., \& Borreani, G. (2011). Aflatoxin accumulation in whole crop maize silage as a result of aerobic exposure. Journal of the Science of Food and Agriculture, 91(13), 24192425. doi: $10.1002 / j s f a .4481$

Cherney, J. H., \& Cherney, D. J. R. (2003). Assessing silage quality. In D. R. Buxton, R. E. Muck, \& J. H. Harrison (Eds.), Silage science and technology (pp. 141-198). Madison, Wisconsin: American Dairy Science Association.

Ferraretto, L. F., \& Shaver, R. D. (2015). Effects of whole-plant corn silage hybrid type on intake, digestion, ruminal fermentation, and lactation performance by dairy cows through a meta-analysis. Journal of Dairy Science, 98(4), 2662-2675. doi: 10.3168/ jds.2014-9045

Fijałkowska, M., Pysera, B., Lipiński, K., \& Strusińska, D. (2015). Changes of nitrogen compounds during ensiling of high protein herbages-a review. Annals of Animal Science, 15(2), 289-305. doi: 10.1515/ aoas-2015-0008

Gallo, A., Guibert, G., Frisvad, J. C., Bertuzzi, T., \& Nielsen, K. F. (2015). Review on mycotoxin issues in ruminants: occurrence in forages, effects of mycotoxin ingestion on health status and animal performance and practical strategies to counteract their negative effects. Toxins, 7(8), 3057-3111. doi: 10.3390/toxins 7083057

Goes, R. H. T. B., Souza, K. A., Patussi, R. A., Cornelio, T. C., Oliveira, E. R. de, \& Brabes, K. C. S. (2010). Degradabilidade in situ dos grãos de crambe, girassol e soja, e de seus coprodutos em ovinos. Acta Scientiarum. Animal Sciences, 32(3), 271-277. doi: 10. 4025/actascianimsci.v32i3.7913

Goeser, J. P., \& Combs, D. K. (2009). An alternative method to assess $24-h$ ruminal in vitro neutral detergent fiber digestibility. Journal of Dairy Science, 92(8), 38333841. doi: 10.3168/jds.2008-1136

Junga, P., \& Trávnícek, P. (2015). Surface temperature of the exposed silo face as quick indicator of the decomposition process of maize silage. Journal of Central European Agriculture, 16(1), 76-91. doi: 10.5513/JCEA01/16.1.1544

Kung, L., Jr., Shaver, R. D., Grant, R. J., \& Schmidt, R. J. (2018). Silage review: Interpretation of chemical, microbial, and organoleptic components of silages. Journal of Dairy Science, 101(5), 4020-4033. doi: 10.3168/ jds.2017-13909

Lima, L. M., Santos, J. P. dos, Casagrande, D. R., Ávila, C. L. S., Lara, M. S., \& Bernardes, T. F. (2017). Lining bunker walls with oxygen barrier film reduces nutriente losses in corn silages. Journal of Dairy Science, 100(6), 4565-4573. doi: 10.3168/jds.201612129

Manual de adubação de calagem para o Estado do Paraná (2017). Sociedade Brasileira de Ciência do Solo. Curitiba: SBCS/NEPAR. 
Neumann, M., Leão, G. F. M., Askel, E. J., Marafon, F., Figueira, D. N., \& Poczynek, M. (2017). Sealing type effect on corn silage quality in bunker silos. Ciência Rural, 47(5), 1-6. doi: 10.1590/0103-8478cr 20160643

Neumann, M., Oliveira, M., Zanette, P., Ueno, R., Marafon, F., \& Souza, M. (2011). Aplicação de procedimentos técnicos na ensilagem do milho visando maior desempenho animal. Anais do Simpósio Produção e Utilização de Forragens Conservadas, Maringá, PR, Brasil, 4.

Nocek, J. E. 1988. In situ and other methods to estimate ruminal protein and energy digestibility. A review. Journal Dairy Science, 71(8), 2051-206. doi: 10.3168/ jds.S0022-0302(88)79781-7

Orskov, E. R., \& McDonald, I. (1979). The estimation of protein degradability in the rumen from incubation measurements weighted according to rate of passage. The Journal of Agricultural Science, 92(2), 499508. doi: $10.1017 /$ S0021859600063048

Pott, C. A., Müller, M. M. L., \& Bertelli, P. B. (2007). Adubação verde como alternativa agroecológica para recuperação da fertilidade do solo. Revista Ambiência, 3(1), 51-63.

Price, J. D. A. (1969). Modification of the barker summer son method for the determination of lactic acid. Afialyst, 94(1125), 11511152. doi: 10.1039/AN9699401151

Statistical Analysis System Institute (1993). SAS language reference. Version 6. Cary, NC: SAS Institute.
Silva, D. J., \& Queiroz, A. C. (2009). Análise de alimentos, métodos químicos e biológicos ( $3^{a}$ reimp.). Viçosa: Universidade Federal de Viçosa.

Tabacco, E., Ferrero, F., \& Borreani, G. (2020). Feasibility of utilizing biodegradable plastic film to cover corn silage under farm conditions. Applied Sciences, 10(8), 2803. doi: 10.3390/app10082803

Tabacco, E., Righi, F., Quarantelli, A., \& Borreani, G. (2011). Dry matter and nutritional losses during aerobic deterioration of corn and sorghum silages as influenced by different lactic acid bacteria inocula. Journal Dairy Science, 94(3), 1409-1419. doi: 10.3168/ jds.2010-3538

Van Soest, P. V., Robertson, J. B., \& Lewis, B. A. (1991). Methods for dietary fiber, neutral detergent fiber, and nonstarch polysaccharides in relation to animal nutrition. Journal of Dairy Science, 74(10), 3583-3597. doi: 10.3168/jds.S0022-0302 (91)78551-2

Wilkinson, J. M., \& Davies, D. R. (2013). The aerobic stability of silage: key findings and recent developments. Grass and Forage Science, 68(1), 1-19. doi: 10.1111/j.13652494.2012.00891.x

Wilkinson, J. M., \& Fenlon, J. S. (2014). A metaanalysis comparing standard polyethylene and oxygen barrier film in terms of losses during storage and aerobic stability of silage. Grass Forage Science, 69(3), 385392. doi: $10.1111 /$ gfs. 12087 
